\title{
Karakter Organisme Biologis dalam Bioremediasi - Review
}

\section{The Character of Biological Organisms at Bioremediation - A Review}

\author{
Evitasari $^{\text {* }}$, Geo Aghni Bintan Sukono ${ }^{1}$, Farhan Rahmatullah Hikmawan ${ }^{1}$, Dodi Satriawan ${ }^{1}$ \\ 1,2,3,4 Teknik Pengendalian Pencemaran Lingkungan, Politeknik Negeri Cilacap, Indonesia. \\ Email : ${ }^{1}$ evitasari2906@gmail.com, ${ }^{2}$ geoaghni300@gmail.com, ${ }^{3}$ farhanhikmawan27@gmail.com, \\ ${ }^{4}$ dodi.satriawan@pnc.ac.id
}

Direview : 7 Agustus 2020

Diterima : 20 Agustus 2020

\begin{abstract}
Abstrak
Logam berat dan polutan organik dianggap sebagai masalah lingkungan yang signifikan bagi kesehatan manusia. Pencemaran tanah dan badan air oleh polutan organik dan logam beracun telah meningkat selama beberapa tahun terakhir karena industrialisasi, pertanian intensif, dan aktivitas antropogenik. Pembuangan limbah industri dan limbah kota perkotaan ke lingkungan akuatik yang tidak pandang bulu dan tidak terbatas telah menjadi masalah perhatian global utama. Salah satu metode untuk menangani pencemaran tersebut adalah dengan penggunaan organisme biologis. Teknik atau proses penggunaan organisme biologis untuk menghancurkan, atau mengurangi limbah berbahaya di lokasi yang terkontaminasi disebut dengan bioremediasi. Bioremediasi adalah metode pengolahan limbah paling baik untuk mengendalikan pencemaran lingkungan dan memulihkan tanah yang terkontaminasi. Penggunaan bahan biologis, digabungkan dengan proses lanjutan lainnya adalah salah satu pendekatan yang paling menjanjikan dan murah untuk menghilangkan polutan lingkungan. Teknik bioremediasi merupakan salah satu alternatif yang bermanfaat untuk menurunkan pencemar. Artikel ini menyajikan organisme biologis penting yang digunakan dalam teknik bioremediasi.
\end{abstract}

Kata kunci: bioremediasi, teknik bioremediasi, organisme biologis, polutan organik, logam beracun.

\begin{abstract}
Heavy metals and organic pollutants are considered to be important environmental issues for human sanity. The pollution of soils and water trunk by organic pollutants and toxic metals has enhanced in current years due to industrialization, anthropogenic zeal, and intensive farming. The haphazard and indiscriminate removal of industrial waste and municipal waste to the aquatic environment has become the main global interest. One method to reckon with this pollution is the utilize of biological organisms. The technology or process of using biological organisms to destroy or reduce hazardous waste in an infected site is called bioremediation. Bioremediation is the best waste treatment method for controlling environmental pollution and restoring contaminated soil. The use of biological materials, combined with other advanced processes is one of the most hopeful and cheap oncomings to eliminate environmental pollutants. The bioremediation technique is a useful choice to degrade pollutants. This article gives the significant biological organisms apply in the bioremediation technique.
\end{abstract}

Keywords: bioremediation, bioremediation technique, biological organisms, organic pollutants, toxic metals. 


\section{PENDAHULUAN}

Logam berat dan polutan organik dianggap sebagai masalah lingkungan yang signifikan bagi kesehatan manusia. Pencemaran tanah dan badan air oleh polutan organik dan logam beracun telah meningkat selama beberapa tahun terakhir karena industrialisasi, pertanian intensif, dan aktivitas antropogenik. Pembuangan limbah industri dan limbah kota atau perkotaan ke lingkungan akuatik yang tidak pandang bulu dan tidak terbatas telah menjadi masalah perhatian global utama (Anas and Setiadi, 2012; Chanif, Hambali and Yani, 2017). Pemuatan berlebih dari limbah yang tidak aman dan berbahaya menyebabkan kekurangan air bersih dan higienis dan gangguan pada tanah sehingga membatasi produksi tanaman (Chorom, Sharifi and Motamedi, 2010; Lin, Pan and Cheng, 2010; Jain et al., 2011). Salah satu metode untuk menangani pencemaran tersebut adalah dengan memanfaatkan mikroorganisme.

Mikroorganisme tersebar luas di biosfer karena kemampuan metaboliknya yang sangat mengesankan dan dapat dengan mudah tumbuh dalam berbagai kondisi lingkungan. Keragaman nutrisi mikroorganisme juga dapat dimanfaatkan untuk biodegradasi polutan. Sebagian besar bahan kimia organik dan banyak bahan anorganik menjadi sasaran serangan enzimatik melalui aktivitas organisme hidup. Sebagian besar pencemar lingkungan masyarakat modern termasuk di antara bahan kimia ini, dan tindakan enzimatik ini biasanya dikelompokkan di bawah istilah biodegradasi (Roy et al., 2018).

Penggunaan proses biodegradasi secara produktif untuk menghilangkan atau mendetok-sifikasi polutan yang telah masuk ke lingkungan dan mengancam kesehatan masyarakat, biasanya karena kontaminan tanah, air, atau sedimen disebut bioremediasi (Chorom, Sharifi and Motamedi, 2010; Jain et al., 2011; Scoma, Yakimov and Boon, 2016). Hal ini dilanjutkan berdasarkan kemampuan mikroorganisme tertentu untuk mengubah, memodifikasi dan memanfaatkan polutan beracun untuk memperoleh energi dan produksi biomassa dalam prosesnya (Jain et al., 2011).

Alih-alih hanya mengumpulkan polutan dan menyimpannya, bioremediasi merupakan aktivitas prosedural yang terorganisir dengan baik secara mikrobiologis yang diterapkan untuk memecah atau mengubah kontaminasi menjadi bentuk unsur dan senyawa yang kurang beracun atau tidak beracun (Quintella, Mata and Lima, 2019). Bioremediator adalah agen biologis yang digunakan untuk bioremediasi untuk membersihkan daerah yang terkontaminasi. Bakteri, archaea dan fungi merupakan bioremediator utama yang biasa digunakan (Beškoski et al., 2011; Karlapudi et al., 2018).

Penerapan bioremediasi sebagai proses bioteknologi yang melibatkan mikroorganisme untuk memecahkan dan menghilangkan bahaya polutan melalui biodegradasi dari lingkungan. Istilah bioremidasi dan biodegradasi adalah kata yang lebih bisa digunakan.

Tabel 1. Bioakumulasi dan biotransformasi senyawa organik oleh bakteri

\begin{tabular}{|l|l|}
\hline \multicolumn{1}{|c|}{ Bekteri } & \multicolumn{1}{c|}{ Kimia Beracun } \\
\hline Bacillus $s p$ & Cresol, fenol, aromatik, alkana rantai panjang. \\
Pseudomonas $s p$ & Benzen, antrasin, hidrokarbon, PCBs \\
Flavobacterium $s p$ & Aromatik \\
Azotobacter $s p$ & Aromatik \\
Xanthomonas $s p$ & Hidrokarbon, Hidrokarbon polisiklik \\
Nocardia $s p$ & Hidrokarbon \\
Streptomyces $s p$ & Fenosiasetat, Hidrokarbon halogen, diazinon \\
Mycobacterium $s p$ & Aromatik, hidrokarbon benzen bercabang, siklofarafin \\
\hline
\end{tabular}

Mikroorganisme bertindak sebagai alat penghilang polutan yang signifikan di tanah, air, dan sedimen; sebagian besar karena keunggulan mereka dibandingkan protokol prosedural remediasi lainnya. Mikroorganisme memulihkan lingkungan alami asli dan mencegah pencemaran lebih lanjut. Tujuan dari tinjauan untuk mengungkapkan tren saat ini berupa aplikasi atau peran mikroorganisme pada bioremediasi dan untuk memberikan kontribusi latar belakang yang relevan yang mengidentifikasi celah dalam bidang

DOI : 10.35970/jppl.v2i2.350

Corresponding Author : evitasari2906@gmail.com,dodi.satriawan@pnc.ac.id 
tematik ini. Saat ini merupakan penelitian yang lagi membuming karena mikroorganisme merupakan salah satu treatment yang ramah lingkungan dan menjanjikan serta materi genetik yang berharga untuk mengatasi ancaman lingkungan.

\section{MEKANISME BIOREMEDIASI}

Bioremediasi adalah sistem pengolahan biologis untuk menghilangkan, atau mengurangi konsentrasi limbah berbahaya dari lokasi yang tercemar (Munawar and Zaidan, 2013). Beberapa definisi membatasi penggunaan mikroba saja sementara yang lain tampaknya memasukkan semua entitas biologis seperti tumbuhan (fitoremediasi). Apapun didefinisi dari bioremediasi, sebenarnya di alam proses remediasi biologis melibatkan baik tumbuhan maupun mikroba dan justru interaksi tumbuhan-mikroba di zona perakaran memiliki peran yang sangat penting. Kadar keasaman atau $\mathrm{pH}$ merupakan faktor penting yang mempengaruhi adsorpsi (Roy et al., 2018). (Jain et al., 2011) menunjukkan bahwa dengan penurunan pH, jumlah area pengikatan mikroorganisme berkurang dan $\mathrm{pH}$ meningkat selama pendegradasi ion logam.

\subsection{Agen Bioremediasi}

Organisme alami, baik berasal dari tempat terkontaminasi maupun tambahan dari luar, adalah agen penting yang digunakan untuk bioremediasi (Juliani and Rahman, 2011). Organisme bervariasi, tergantung pada sifat kimiawi dari zat pencemar, dan harus dipilih dengan hati-hati karena mereka hanya bertahan dalam batas tertentu dari kontaminan kimia (Al-Mailem et al., 2010; Atlas and Hazen, 2011). Paten pertama untuk bahan remediasi biologis dicatat pada tahun 1974, adalah strain Pseudomonas putida yang mampu mendegradasi minyak bumi (Al-Mailem, Eliyas and Radwan, 2013). Bioremediasi tersebut dapat terjadi secara alami atau melalui proses intervensi (Al-Mailem, Eliyas and Radwan, 2013).

\subsection{Bioremediasi Oleh Bakteri}

Tabel 2. Bakteri yang dapat mendegradasi logam berat

\begin{tabular}{|l|l|}
\hline \multicolumn{1}{|c|}{ Bekteri } & \multicolumn{1}{c|}{ Logam berat } \\
\hline Bacillus $s p$ & $\mathrm{Cu}, \mathrm{Zn}$ \\
Pseudomonas aeruginosa & $\mathrm{U}, \mathrm{Cu}, \mathrm{Ni}, \mathrm{Cr}$ \\
Aerococcus $s p$ & $\mathrm{~Pb}, \mathrm{Cr}, \mathrm{Cd}$ \\
Aeromonas $s p$ & $\mathrm{Cr}$ \\
Rhodopseudomonas palustris & $\mathrm{Pb}, \mathrm{Cr}, \mathrm{Cd}$ \\
Citrobacter sp & $\mathrm{Cd}, \mathrm{U}, \mathrm{Pb}$ \\
\hline
\end{tabular}

Mikroba / mikroorganisme sering dilaporkan sebagai media degradasi pestisida dan hidrokarbon (Xu and Lu, 2010; Retno and Mulyana, 2013; Roy et al., 2014). Sejumlah besar bakteri memanfaatkan kontaminan sebagai satu-satunya sumber karbon dan energi. Sejumlah mikroorganisme tercantum dalam Tabel 1 dan Tabel 2. Logam memainkan peran penting dalam proses kehidupan mikroba. Beberapa logam seperti kromium $(\mathrm{Cr})$, kalsium $(\mathrm{Ca})$, magnesium $(\mathrm{Mg})$, mangan $(\mathrm{Mn})$, tembaga $(\mathrm{Cu})$, natrium $(\mathrm{Na})$, nikel $(\mathrm{Ni})$ dan seng $(\mathrm{Zn})$ sangat penting sebagai mikronutrien untuk berbagai metabolisme dan untuk fungsi redoks (Martin et al., 2010; Radwan et al., 2010; Ron and Rosenberg, 2014).

\subsubsection{Faktor yang Mempengaruhi Bioreme-Diasi Bakteri}

Bioremediasi terlibat dalam mendegradasi, menghilangkan, mengubah, melumpuhkan, atau mendetoksifikasi berbagai bahan kimia dan limbah fisik dari lingkungan melalui aksi bakteri, fungi dan tumbuhan(Atlas and Hazen, 2011). Mikroorganisme yang terlibat melalui jalur enzimatik bertindak sebagai biokatalis dan memfasilitasi kemajuan reaksi biokimia yang menurunkan polutan yang 
diinginkan (Atlas and Hazen, 2011). Mikroorganisme bertindak mendagradasi polutan hanya jika mikroorganisme berada pada berbagai bahan senyawa untuk membantu mereka menghasilkan energi dan nutrisi untuk membangun lebih banyak sel. Efisiensi bioremediasi bergantung pada banyak faktor; termasuk, sifat kimiawi dan konsentrasi polutan, karakteristik fisikokimia lingkungan, dan ketersedia nutrien untuk mikroorganisme (Bezza and Chirwa, 2015).

Alasan laju degradasi turun diantaranya karena bakteri dan polutan tidak saling bersentuhan. Selain itu, penyebaran mikroba dan polutan di lingkungan tidak merata. Pengendalian dan optimalisasi proses bioremediasi merupakan sistem yang kompleks karena banyak faktor. Faktor-faktor tersebut termasuk keberadaan populasi mikroba yang mampu mendegradasi polutan, ketersediaan kontaminan terhadap populasi mikroba dan faktor lingkungan sepert jenis tanah, suhu, $\mathrm{pH}$, keberadaan oksigen atau akseptor elektron lainnya, dan nutrisi (Atlas and Hazen, 2011; Beškoski et al., 2011) .

\subsection{Bioremediasi Oleh Mikroalga}

Tabel 3. Bioakumulasi dan biotransformasi senyawa organik oleh fungi

\begin{tabular}{|l|l|}
\hline \multicolumn{1}{|c|}{ Fungi } & \multicolumn{1}{c|}{ Senyawa toxik } \\
\hline Coprinellus radians & PAHs, methylnaphthalenes, and dibenzofurans \\
Marasmiellus troyanus & Benzo [a] pirene \\
Gloeophyllum trabeum & $1,1,1$-trichloro-2, 2-bis (4-chlorophenyl) ethane (DDT) \\
Pleurotus ostreatus & Bisphenol A \\
Fomitopsis pinicola & $1,1,1$-trichloro-2, 2-bis (4-chlorophenyl) ethane (DDT) \\
Penicillium simplicissimum & Polyethelene \\
Phanerochaete chrysosporium & Polyvinylamine sulfonate anthrapyridone \\
\hline
\end{tabular}

Biodegradasi pestisida ditentukan oleh dua faktor(Atlas and Hazen, 2011). Faktor pertama berkaitan dengan konsorsium mikroalga dan kondisi optimum untuk kelangsungan hidup dan aktivitasnya. Faktor kedua berkaitan dengan struktur kimiawi pestisida. Faktor-faktor yang berhubungan dengan mikroalga termasuk keberadaan dan jumlah alga yang sesuai, kontak antara alga dan substrat (pestisida), pH, suhu, salinitas, nutrisi, kualitas dan intensitas cahaya, air yang tersedia, keberadaan oksigen dan potensial redoks, surface binding, keberadaan substrat karbon alternatif dan akseptor elektron alternatif (Chorom, Sharifi and Motamedi, 2010; Atlas and Hazen, 2011; Bezza and Chirwa, 2015). (Quintella, Mata and Lima, 2019) menunjukkan bahwa tidak hanya mikroalga yang memiliki kemampuan untuk bioakumulasi pestisida, tetapi juga mampu melakukan biotransformasi beberapa kontaminan di lingkungan.

Kemampuan mikroalga dalam menyerap logam berbahaya telah dikenal selama bertahun-tahun. Mikroalga memiliki kemampuan untuk menghilangkan logam berat beracun dari lingkungan yang memiliki konsentrasi lebih tinggi daripada air di sekitarnya (Baihaqi et al., 2018; Quintella, Mata and Lima, 2019). Mikroalga dan organisme fotosintetik eukariotik terkait, telah secara eksklusif mengembangkan produksi peptida berbeda yang mampu menekan atau mereduksi logam berat (Quintella, Mata and Lima, 2019). Kompleks organologam ini selanjutnya dipisahkan di dalam vakuola yang memfasilitasi regulasi yang tepat dari konsentrasi ion logam berat sitoplasma, sehingga menetralkan atau mencegah efek toksiknya (Quintella, Mata and Lima, 2019) 
Tabel 4. Fungi yang dapat mendegradasi logam berat

\begin{tabular}{|l|l|}
\hline \multicolumn{1}{|c|}{ Fungi } & \multicolumn{1}{|c|}{ Logam Berat } \\
\hline Rhizopus arrhizus & $\mathrm{Ag}, \mathrm{Hg}$ \\
Stereum hirsutum & $\mathrm{Cd}, \mathrm{Pb}$ \\
\hline
\end{tabular}

\subsection{Bioremediasi Oleh Fungi}

Fungi merupakan kelompok mikroba yang menjanjikan untuk biodegradasi (Tabel 3 dan Tabel 4). Kemampuan fungi, baik ragi maupun kapang, untuk mengubah berbagai macam zat kimia berbahaya telah mengembangkan minat untuk menggunakannya dalam bioremediasi (Lestari et al., 2018; Quintella, Mata and Lima, 2019). Fungi dapat memineralisasi senyawa xenobiotik menjadi $\mathrm{CO}_{2}$ dan $\mathrm{H}_{2} \mathrm{O}$ melalui sistem enzim ligninolitik non-spesifik dan sangat oksidatif, yang juga bertanggung jawab untuk degradasi dan dekolorisasi berbagai pewarna (Lestari et al., 2018; Quintella, Mata and Lima, 2019).

\subsection{Bioremediasi Oleh Tanaman}

Fitoremediasi sangat sesuai untuk aplikasi di tanah dengan kelembapan rendah, di mana sebagian besar teknologi yang saat ini digunakan memiliki tingkat keberhasilan yang rendah, serta dikombinasikan dengan teknologi penghilangan yang lebih konvensional. Dalam situasi yang tepat, fitoremediasi dapat menjadi pengganti teknologi remediasi fisik dan kimiawi yang jauh lebih baik dari penguapan termal, pencucian dengan pelarut, pembakaran atau teknik pencucian tanah lainnya, yang pada dasarnya menurunkan unsur-unsur biologis tanah dan dapat secara intens mengubah sifat fisik dan kimianya (Beškoski et al., 2011; Hassanshahian et al., 2014; Roy et al., 2018). Fitoremediasi dapat memperbaiki tanah, meninggalkan ekosistem tanah yang lebih baik, efektif, dengan biaya yang diperkirakan sekitar sepersepuluh dari metode yang digunakan saat ini (Chorom, Sharifi and Motamedi, 2010).

\section{KESIMPULAN}

Tanah dan air tercemar oleh berbagai polutan organik dan anorganik disebabkan oleh industrialisasi yang pesat dan penggunaan bahan kimia pertanian dalam komposisi yang tidak seimbang. Tindakan pembatasan dan pembersihan untuk mencegah bahaya dari tanah yang terkontaminasi termasuk dalam perlindungan terhadap kestabilisasi tanah. Bioremediasi adalah teknik unik dan hemat biaya untuk membersihkan polutan dengan mengintensifkan proses biodegradasi alami. Pengembangkan pemahaman sangat penting tentang mikroba, mikroalga, fungi dan tanaman terhadap tingkah laku mereka di lingkungan alam dan kontaminan, serta pengetahuan tentang genetika mikroorganisme dapat membantu meningkatkan kemampuan untuk menurunkan polutan dan pemulihan tanah dan air terkontaminasi.

\section{PENGHARGAAN}

Kami sampaikan terimakasi sebesar-besarnya kepada SIMBELMAWA KEMENDIKBUD yang telah memberikan kesempatan kepada kami melalui Program Kreativitas Mahasiswa (PKM) dengan dana Hibah penelitian. Dan tak lupa kami ucapkan dengan tulus hati kepada dosen pembimbing PKM kami, Bapak Dodi Satriawan, S.T., M.Eng yang sangat telaten dan sabar membimbing kami dalam program PKM tahun 2020 ini. 


\section{DAFTAR PUSTAKA}

Al-Mailem, D. M. et al. (2010) 'Oil-bioremediation potential of Arabian Gulf mud flats rich in diazotrophic hydrocarbon-utilizing bacteria', International Biodeterioration \& Biodegradation, 64(3), pp. 218 225. doi: 10.1016/j.ibiod.2010.01.007.

Al-Mailem, D. M., Eliyas, M. and Radwan, S. S. (2013) 'Oil-bioremediation potential of two hydrocarbonoclastic, diazotrophic Marinobacter strains from hypersaline areas along the Arabian Gulf coasts', Extremophiles, 17(3), pp. 463-470. doi: 10.1007/s00792-013-0530-z.

Anas, I. and Setiadi, Y. (2012) 'Produksi Gas Karbon Dioksida Selama Proses Bioremediasi Limbah Heavy Oil Dengan Teknik Landfarming', Chemistry Progress, 3(1), pp. 1-5. doi: 10.35799/cp.3.1.2010.66.

Atlas, R. M. and Hazen, T. C. (2011) 'Oil Biodegradation and Bioremediation: A Tale of the Two Worst Spills in U.S. History', Environmental Science \& Technology, 45(16), pp. 6709-6715. doi: $10.1021 / \mathrm{es} 2013227$.

Baihaqi, B. et al. (2018) 'BIOREMEDIASI LIMBAH CAIR KELAPA SAWIT DENGAN MENGGUNAKAN Spirogyra sp', BIOTIK: Jurnal Ilmiah Biologi Teknologi dan Kependidikan, 5(2), p. 125. doi: $10.22373 /$ biotik.v5i2.3021.

Beškoski, V. P. et al. (2011) 'Ex situ bioremediation of a soil contaminated by mazut (heavy residual fuel oil) - A field experiment', Chemosphere, 83(1), pp. 34-40. doi: 10.1016/j.chemosphere.2011.01.020.

Bezza, F. A. and Chirwa, E. M. N. (2015) 'Production and applications of lipopeptide biosurfactant for bioremediation and oil recovery by Bacillus subtilis CN2', Biochemical Engineering Journal, 101(October), pp. 168-178. doi: 10.1016/j.bej.2015.05.007.

Chanif, I., Hambali, E. and Yani, M. (2017) 'Kinerja Oil Spill Dispersant Dalam Proses Bioremediasi Tanah Tercemar Minyak Bumi (Studi Kasus Tanah Tercemar Minyak Bumi Lapangan XYZ)', Jurnal Teknologi Industri Pertanian, 27(3), pp. 336-344. doi: 10.24961/j.tek.ind.pert.2017.27.3.336.

Chorom, M., Sharifi, H. S. and Motamedi, H. (2010) 'Bioremediation of a crude oil - polluted soil by application of fertilizers', Iranian Journal of Environmental Health Science and Engineering, 7(4), pp. 319-326.

Hassanshahian, M. et al. (2014) 'Bioremediation (bioaugmentation/biostimulation) trials of oil polluted seawater: A mesocosm simulation study', Marine Environmental Research, 95, pp. 28-38. doi: 10.1016/j.marenvres.2013.12.010.

Jain, P. K. et al. (2011) 'Bioremediation of Petroleum oil Contaminated Soil and Water', Research Journal of Environmental Toxicology, 5(1), pp. 1-26. doi: 10.3923/rjet.2011.1.26.

Juliani, A. and Rahman, F. (2011) 'Bioremediasi Lumpur Minyak (Oil Sludge) dengan Penambahan Kompos sebagai Bulking Agent dan Sumber Nutrien Tambahan', Jurnal Sains \& Teknologi Lingkungan, 3(1), pp. 01-18. doi: 10.20885/jstl.vol3.iss1.art1.

Karlapudi, A. P. et al. (2018) 'Role of biosurfactants in bioremediation of oil pollution-a review', Petroleum, 4(3), pp. 241-249. doi: 10.1016/j.petlm.2018.03.007.

Lestari, W. et al. (2018) 'POTENSI JAMUR INDIGENUS RIAU (Penicillium sp.PN6) DAN Neptunia oleracea UNTUK BIOREMEDIASI OIL SLUDGE', Al-Kauniyah: Jurnal Biologi, 11(1), pp. 72-81. doi: 10.15408/kauniyah.v11i1.6350.

Lin, T.-C., Pan, P.-T. and Cheng, S.-S. (2010) 'Ex situ bioremediation of oil-contaminated soil', Journal of Hazardous Materials, 176(1-3), pp. 27-34. doi: 10.1016/j.jhazmat.2009.10.080.

Martin, J. W. et al. (2010) 'Ozonation of Oil Sands Process-Affected Water Accelerates Microbial Bioremediation', Environmental Science \& Technology, 44(21), pp. 8350-8356. doi: 10.1021/es101556z.

Munawar, M. and Zaidan, Z. (2013) 'Bioremediasi Limbah Minyak Bumi dengan Teknik Biopile di Lapangan Klamono Papua', Jurnal Sains \& Matematika, pp. 41-46.

Quintella, C. M., Mata, A. M. T. and Lima, L. C. P. (2019) 'Overview of bioremediation with technology assessment and emphasis on fungal bioremediation of oil contaminated soils', Journal of Environmental Management, 241(April), pp. 156-166. doi: 10.1016/j.jenvman.2019.04.019.

Radwan, S. et al. (2010) 'Identities of Epilithic Hydrocarbon-Utilizing Diazotrophic Bacteria from the Arabian Gulf Coasts, and Their Potential for Oil Bioremediation Without Nitrogen Supplementation', Microbial Ecology, 60(2), pp. 354-363. doi: 10.1007/s00248-010-9702-x.

DOI : 10.35970/jppl.v2i2.350

Corresponding Author : evitasari2906@gmail.com,dodi.satriawan@pnc.ac.id 
Retno, T. and Mulyana, N. (2013) 'Bioremediasi Lahan Tercemar Limbah Lumpur Minyak Menggunakan Campuran Bulking Agents yang Diperkaya Konsorsia Mikroba Berbasis Kompos Iradiasi Bioremediation of Oil Sludge Contaminated Soil Using Bulking Agent Mixture Enriched Consortia of Microbial Inocu', Jurnal Ilmiah Aplikasi Isotop dan Radiasi, 9(2), pp. 139-150. doi: 10.17146/jair.2013.9.2.2738.

Ron, E. Z. and Rosenberg, E. (2014) 'Enhanced bioremediation of oil spills in the sea', Current Opinion in Biotechnology, 27, pp. 191-194. doi: 10.1016/j.copbio.2014.02.004.

Roy, A. et al. (2018) 'Biostimulation and bioaugmentation of native microbial community accelerated bioremediation of oil refinery sludge', Bioresource Technology, 253, pp. 22-32. doi: 10.1016/j.biortech.2018.01.004.

Roy, A. S. et al. (2014) 'Bioremediation potential of native hydrocarbon degrading bacterial strains in crude oil contaminated soil under microcosm study', International Biodeterioration \& Biodegradation, 94, pp. 79-89. doi: 10.1016/j.ibiod.2014.03.024.

Scoma, A., Yakimov, M. M. and Boon, N. (2016) 'Challenging Oil Bioremediation at Deep-Sea Hydrostatic Pressure', Frontiers in Microbiology, 7(AUG). doi: 10.3389/fmicb.2016.01203.

$\mathrm{Xu}, \mathrm{Y}$. and $\mathrm{Lu}, \mathrm{M}$. (2010) 'Bioremediation of crude oil-contaminated soil: Comparison of different biostimulation and bioaugmentation treatments', Journal of Hazardous Materials, 183(1-3), pp. 395401. doi: 10.1016/j.jhazmat.2010.07.038. 